\title{
Ecotourism Practices in Sri Lankan Eco Resorts: A Supplier Perspective Analysis
}

\author{
Rangana Sri Shalika Wadippuli Arachchi \\ Sabaragamuwa University of Sri Lanka, Sabaragamuwa, Sri Lanka \\ Mohd Shukri Ab. Yajid, Ali Khatibi \\ Management Science University, Shah Alam, Malaysia
}

\begin{abstract}
Ecotourism is potentially the best growing segment in the international market. Many hoteliers in Sri Lanka promote the sustainable use of this concept as a new market-oriented concept. However, arrivals of eco tourists to Sri Lanka have been less than $1 \%$ over the last decade. A comprehensive case study research approach was used to conduct this research. Interpretive paradigm and the social constructionists' philosophical stand of the researchers provided the opportunity to explore or describe a phenomenon in context using a variety of data sources. In the sample, managerial level staffs were selected to conduct in-depth interviews to explore the meaning of the term "eco resort". Analysis of in-depth interviews and observations showed that the practice of the eco resort concept has been misused by the hoteliers in Sri Lanka. They have been unable to classify the eco tourists and identify the market and customer segment clearly.
\end{abstract}

Keywords: ecotourism, eco resort, international standards, eco resort components, sustainability

\section{Introduction}

\section{Background of the Study}

Tourism is currently one of the most important contributors to the Sri Lankan economy. Tourism continued as the third largest earner of foreign exchange earnings in Sri Lankan economy. According to Silva (2004), attitude of tourists has gradually changed from one that emphasizes beach tourism to one that demands more natural, cultural, and social interactions. He further emphasized the new phenomenon, which is broadly termed as "alternative tourism". As a result, the concept of ecotourism emerged with the collaboration of cultural, rural, nature tourism, and its related activities as a niche market.

The term "ecotourism" was first coined in July 1983 by Hector Ceballos-Lascurain, an architect, environmentalist, and ecotourism consultant from Mexico (Planeta). The original definition was as follows:

Ecotourism is environmentally responsible travel and visitation to relatively undisturbed natural areas, in order to enjoy and appreciate nature (and any accompanying cultural features - both past and present) that promotes conservation, has low negative visitor impact, and provides for beneficially active socio-economic involvement of local populations. (Ceballos-Lascurain, 2005)

Rangana Sri Shalika Wadippuli Arachchi, senior lecturer, Department of Tourism Management, Sabaragamuwa University of Sri Lanka. Email: rangana@sab.ac.lk; ranganashalika1980@gmail.com.

Mohd Shukri Ab. Yajid, president, Management Science University.

Ali Khatibi, dean, Faculty of Business Management and Professional Studies, Management Science University. 
Being a good business opportunity and the fastest growing segment in the tourism industry, Sri Lankan tourism is changing its outlook to sustain this new product. Since Sri Lanka is rich with much cultural and natural diversity, it has the potential to develop the ecotourism concept better than other destinations for the benefit of the Sri Lankan economy and community. Therefore, applying the ecotourism concept to Sri Lankan hotel industry will encourage a close interaction with the natural and cultural environment and give more economic benefits to the country.

Ecotourism provides many benefits to the society, including the protection of eco system, increase in the foreign exchange of the country and living standards of people, swift regional development, reduction of waste, minimization of the negative impacts to the environment, etc.. Since ecotourism is potentially the fastest growing segment in the international market and it holds great potential for Sri Lanka as a means of conserving biological diversity and promoting the sustainable use of bio-diversity, many hoteliers tend to practice the concept as a novel market-oriented concept. Therefore, global coordinated marketing campaigns were launched to attract eco tourists focusing their needs and wants profitably (Mid-term strategic plan for Sri Lanka tourism 2002-2004). Achieving genuine ecotourism may be viewed as either a difficult technical challenge or an impossible task. Some observe that those who hold the reins of power and money will always prevail and that ecotourism will never genuinely offer benefits to local people and customers (Boo, 1990). When comes to ecotourism, hoteliers have to practice it as meeting the expectations of the customers. It is the practice of ecotourism from the customer-oriented perspective. If the hoteliers fail to apply the customer orientation concept properly, they will not be able to achieve the customer expectations. Multinational hotel chains, resorts, tour operators, and powerful foreign owners often engage in unfair trade practices in ecotourism that allow them to squeeze economic control from local communities where the tourism activities take place (Mastny, 2002). Therefore, eco tourists are trapped in their misleading the eco concept.

Based on these findings, we try to identify the issue of practicing the concept of genuine ecotourism and meeting the customer expectations. Then, it is important to explore this phenomenon in Sri Lankan context to find out whether there is an impact of ecotourism practices in eco resorts on the arrival of eco tourists. Therefore, we will do some short preliminary interviews over the telephone with both ecotourism professionals and eco resort hoteliers to get an idea about the hoteliers' practices.

\section{Research Issue}

Ecotourism is an important tool for conservation and it was proven in certain cases; it has improved the living standards of local people. P. Gurusinghe, President of Sri Lanka Eco Tourism Foundation (personal communication, August 30,2011), described that many eco resorts in Sri Lanka are practicing Trojan horse marketing tourism as environmental friendly, but in fact destroying the every eco system they claim to protect. As a result, customers are dissatisfied with the service of the eco tourist hotels. It can be proved through the mid-term strategic plan for Sri Lanka tourism 2002-2004 (Sri Lanka Tourism and Development Authority [SLTDA], 2001). It states that Sri Lanka had 400,414 tourists in 2000 out of which $1 \%$ was eco tourists. They were identified based on the purpose of arrival that they mentioned at the airport.

Comparing to Sri Lanka, other Asian, African, and European countries are having many demands for ecotourism and eco resorts. Some facts mentioned in the Ecotourism Statistical Fact Sheet (The International Ecotourism Society [TIES], 2000) and Global Ecotourism Fact Sheet of TIES (2006) clearly show it, e.g.: 
(1) In Dominica, in the Caribbean, tourists using small, nature-based lodges spend 18 times more than cruise passengers spend while visiting the island;

(2) In Indonesia, $80 \%$ of money for all-inclusive package tours goes to airlines, hotels, and other international companies. Eco-lodges hire and purchase locally, and sometimes put as much as $95 \%$ of money into the local economy;

(3) In US, UK, and Australian market, more than two-thirds of US and Australian travelers and $90 \%$ of British tourists consider active protection of the environment and support of local communities to be part of a hotel's responsibility.

These facts obviously illustrate that if the ecotourism service providers practice the concept properly, customer demand is very high.

As mentioned earlier, in Sri Lanka, arrivals of eco tourists are less than $1 \%$ over the last decade. Therefore, Sri Lankan ecotourism market is not enjoying the benefits of it, such as conservation of culturally and environmentally friendly areas, earning more foreign exchange, getting employments, regional developments (infrastructure, superstructure), increasing the living standards of community, etc. (SLTDA, 2003).

\section{Significance of the Study}

Due to the contribution of tourism sector to foreign exchange earnings and the development of the society, marketing and implementing the tourism concepts properly to the customers is very much significant. While tourism is our third largest foreign income generator, world tourism trend is moving from generic or bulk tourism to more of specific sectors like ecotourism. In addition, it serves the purpose of both high profitability and larger social benefits. Therefore, it is important to understand whether the implementation of ecotourism concept in eco resorts is successful enough to meet the customer expectations. Then, it will provide a clear picture whether the hoteliers really look at the customer orientation or sales orientation.

\section{Scope of the Research}

This study focuses on ecotourism sector in the tourism industry in Sri Lanka. In the ecotourism sector, there are a number of sections which are dealing with the concept such as professional bodies, institutions, societies, experts, hoteliers, etc.. In this study, we will only consider the hotel sector, which practices the ecotourism and the customers who are getting the service from them. Here, eco tourists are considered as the main customers to the eco resort. In this study, we consider only the self-declared eco resorts which are registered under the Sri Lanka Tourist Board hotel classification.

\section{Research Questions}

The research questions of this paper are as follows:

(1) How do the eco resort hoteliers in Sri Lankan ecotourism sector construct the meaning of eco resort?

(2) What are the differences between the Sri Lankan eco resort hoteliers' interpretation and the international standard?

\section{Objectives of the Study}

This paper aims to: (1) explore the construction of the meaning of eco resort concept by Sri Lankan eco resort hoteliers; and (2) investigate the differences between the Sri Lankan eco resort hoteliers' interpretation and the international standard. 


\section{Literature Review}

\section{Ecotourism and Misuse of the Originality}

Tourism is widely believed to be the most rapidly growing global industry. According to World Tourism Organization, ecotourism is believed to be the fastest growing tourism segment (Buckley, 1994; Deaden \& Harron, 1994). However, there is considerable debate over what ecotourism really means.

The term "ecotourism" was first coined in July 1983 by Hector Ceballos-Lascurain, an architect, environmentalist, and ecotourism consultant from Mexico (Planeta). His definition was later revised in 1993 to move the focus to conservation and the role of the tourist from a passive observer of nature to a participant with a responsibility for its preservation:

Ecotourism is environmentally responsible travel and visitation to relatively undisturbed natural areas, in order to enjoy and appreciate nature (and any accompanying cultural features - both past and present) that promotes conservation, has low negative visitor impact, and provides for beneficially active socio-economic involvement of local populations. (Ceballos-Lascurain, 2005)

The main problem that has stemmed from this is that often the term is misused or misinterpreted for developments which do not hold true to the original meaning of ecotourism (Ross \& Wall, 1999). This is usually attributed to the vagueness of its definitions. With the many meanings and redefinitions over the years, it is hard to regulate it (Font, 2002). It is not only tourism developers that are culprits of redefining the concepts to suit their own purpose, authors of journals and books on the subject are constantly churning out new definitions, each of which is slightly different, concentrating on one or more of its aspects. As ecotourism has grown in popularity, sometimes resembling traditional mass tourism, its definitions have been expanded to incorporate ideas about eco tourist responsibility, environmentally friendly destination management, profit linkages to conservation efforts, and the sustainable development of local human populations (Campbell, 1999). There are many definitions of ecotourism, some of which can be seen in Table 1.

Table 1

Variations of Ecotourism Definitions

\begin{tabular}{|l|l|}
\hline Source & Definition \\
\hline Black (1996) & $\begin{array}{l}\text { "An experience with a focus on the natural and/or cultural environment, and } \\
\text { ecologically sustainable activity, an activity with a predominant educative and } \\
\text { interpretive program, and an activity that contributes to the local community groups } \\
\text { and projects and to the conservation of the surrounding environment" (p. 4). }\end{array}$ \\
\hline Che (2006) & $\begin{array}{l}\text { "Ecotourism has been portrayed as a form of sustainable development, primarily in } \\
\text { Third World pristine settings' as a means of using natural resources to support } \\
\text { economic activity without compromising economic growth, the environmental } \\
\text { carrying capacity, or social equity" (p. 213). } \\
\text { "1. Minimal physical and social impacts on the visited area; 2. Ecological education } \\
\text { of the tourist at the natural site; 3. Notable economic participation by local residents" } \\
\text { (p. 466). }\end{array}$ \\
\hline Clarke (1997) & $\begin{array}{l}\text { "As the position of convergence, whereby large-scale tourism seeks to adopt the policies } \\
\text { and guidelines of sustainability. In short, large business thinks small scale" (p. 225). } \\
\text { "Trips taken in which travelers learn about and appreciate the environment or trips } \\
\text { taken to advance the cause of conservation" (p. 224). } \\
\text { "A form of tourism which fosters environmental principles, with an emphasis on } \\
\text { visiting and observing natural areas. The emphasis on tourism, as much as this can be } \\
\text { separated from recreation, is deliberate" (p. 558). }\end{array}$ \\
\hline Boyd and Butler (1996) & $\begin{array}{l}\text { Ecotourism is usually defined as "responsible travel to natural areas that conserve the } \\
\text { environment and improve the welfare of the local people" (p. 10). }\end{array}$ \\
\hline Lindberg, Furze, Staff, and Blank (1997) (1993) &
\end{tabular}




\section{Ecotourism Practices in Eco Resorts}

Eco resort is an establishment where hospitality services are provided to the eco tourists while practicing ecotourism principles. All eco resorts reflect the creative initiative and entrepreneurialism of business pioneers, rather than large multinational corporations. They can be found in nature tourism destinations around the world. Eco resorts frequently contribute to maintaining official protected areas, because they are often quite dependent on proper management of government-controlled reserves. These eco resorts may actively contribute to trail maintenance, volunteer research programs, clean-up days, or the monitoring of visitor use, depending on the local situation (TIES, 1993).

In addition to TIES, Green Globe 21 standards (Green Globe, n.d.) have guidelines of practicing the ecotourism concept. There are eight principles:

(1) Focus on giving visitors the opportunity to personally and directly experience nature (natural area focus);

(2) Provide opportunities to experience nature in ways that lead to greater understanding, appreciation, and enjoyment (interpretation);

(3) Represent best practice for environmentally sustainable tourism (environmental sustainability practice);

(4) Contribute directly to the conservation of natural areas (contribution to conservation);

(5) Provide ongoing contributions to the local community (benefiting local communities);

(6) Be sensitive to, interpret, and involve the culture/s existing in the area (cultural respect);

(7) Consistently meets consumer expectations (customer satisfaction);

(8) Be marketed and promoted honestly and accurately so that realistic expectations are formed (responsible marketing).

Hotel industry definitely can contribute to protecting the environment following these guidelines. There are many organizations that help in formulating the concept of environmentally friendly hotels. There are various areas in the hotels where these concepts can be incorporated conveniently and smoothly without adversely affecting normal operations or guest satisfaction.

\section{Social Constructionism}

Social constructionism is a term that is used almost exclusively by psychologists (Burr, 2002). It challenges the view that conventional knowledge is based upon objective, unbiased observation of the world. Social constructionists argue concerning the nature of personhood, the role of language in identity, subjectivity and social life, and the historical and cultural specificity of traditional psychology and social psychology.

In addition, social constructionist perspective is now becoming increasingly influential in organizational and management studies (Gold \& Holman, 2001). With the emphasis in management education on language use, attention becomes focused on the types of discursive activity that managers might use in reflection, re-conceptualization, and action, both intra- and interpersonally (Geogakopoulou \& Goutsos, 1997). From a social constructionist perspective, people always have the potential to re-construct their identities, their capabilities, and their lives. Especially qualitative researchers are interested in understanding the meaning people have constructed; how people make sense of their world and experience (Lindergen \& Packendorff, 2009). The existing constructed meanings of eco tourist hotels are based on the foreign countries' perspective. No Asian country has constructed the meaning of it from their perspective. They have just adopted that concept to their country. Therefore, it is important for Sri Lankan ecotourism sector to construct the meaning of it with the view of better customer-oriented practices. 


\section{Methodology}

\section{Research Design}

When conducting a research, it is important to identify the framework for the study. Here, we will use the qualitative research approach to conduct this research. We believe that we can become closer to the actors perspective through detailed interviews and observations. Interpretive paradigm was the based paradigm for this research. Here, we focus on what eco resort means to eco resort hoteliers and check whether their eco practices are customer-oriented or not. Therefore, social constructionists' philosophical stand of us was more helpful to conduct this research.

\section{Strategy of Inquiry}

We did a qualitative case study with the intention of providing a thick description to the concept of eco resort and its customer orientation focus.

\section{Population, Sample, and Sample Selection}

The target population for this study was self-declared eco resorts, which are registered under the SLTDA. Thirty six eco friendly resorts were identified based on the accommodation guide of the SLTDA. Those selected resorts were confirmed as eco-friendly resorts, after verifying their websites. When selecting the cases for the study, scales of number of rooms were used to categorize the resorts according to their size. It is the international scale to classify the hotels in relation to their size. The scale provides the following standards to classify the hotels:

(1) Small-scale hotel: 0-50 (number of rooms);

(2) Medium-scale hotel: 50-100 (number of rooms);

(3) Large-scale hotel: more than 100 (number of rooms).

As a result of the categorization, the following continuum was obtained through the identified population (see Figure 1).

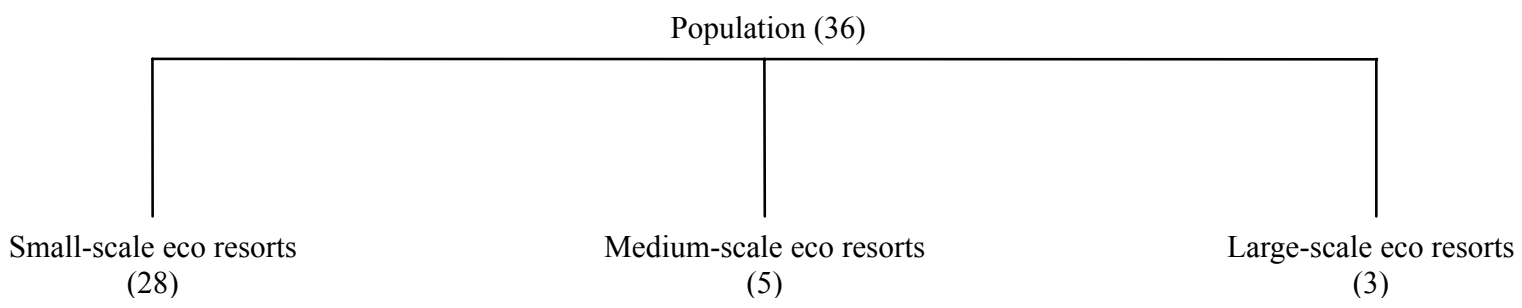

Figure 1. Continuum of resort classification.

Out of the 36 resorts selected, 32 were selected for the study based on the Krejcie and Morgen scale of sample selection. These resorts were selected randomly proportionate to the size of the hotels:

(1) $23 / 36 \times 32=20$ small eco resorts (= RANDBETWEEN $(1,23)$ );

(2) $8 / 36 \times 32=7$ medium eco resorts (= RANDBETWEEN $(1,8)$ );

(3) $5 / 36 \times 32=5$ large eco resorts.

In-depth analysis of each resort was done using various data collection methods. Samples were selected purposively. Therefore, purposive sampling strategy was used in this study. In the sample, resort staff was selected representing the top level of the employees (general managers and AGM) to conduct in-depth 
interviews to explore the meaning of the term "eco resort". There were 53 top-level managers in the selected 32 resorts. Here, we initially conducted 10 in-depth interviews and continued it until it reached the maturation level. Finally, there were 15 in-depth interviews. In these interviews, we paid more consideration to the top-level management since they are the implementers of the ecotourism concept to the hotel. Besides the interview methods, we also utilized the observation method.

The main objective of conducting an observation was to confirm the consistency of data collected through the in-depth interviews. We employed an observation guide with checklist points to check the components of an eco resort. This checklist was prepared covering the major components of an eco resort mentioned in the Green Globe 21 standards and TIES standards. All the 32 eco resorts were observed here and analyzed using the ranking analysis method. Values have been given for each component according to the 5 -point Likert scale as follows: $5=$ Very good; $4=$ Good; $3=$ Average; $2=$ Poor; and $1=$ Very poor.

Here, the average value of 3 was taken as the boundary of the analysis (scale mean). If the components' mean values are higher than the average, it is considered as a good practice. If the mean values are lower than the average value, it is considered as a poor practice of the concept.

\section{Data Collection}

Primary data were collected through in-depth interviews in the research. Interviews were conducted in a semi-structured manner and expected to run for 1-2 hours. Interviews were conducted with the managerial levels of employees of eco resorts. In addition to the interview method, we also used observation method. Here, we utilized an observation guide to check the components of an eco resort.

\section{Results}

In the analysis of ecotourism concept as a main theme, we identified that Sri Lankan eco resort top-level managers define the concept of ecotourism in four various ways as follows:

(1) Nature-related tourism;

(2) Environment conservation tourism;

(3) Wildlife-related tourism;

(4) Nature and cultural related tourism.

These findings show that there is no standard way of understanding the ecotourism concept. The hoteliers looked at the concept in different manners. Sri Lankan hoteliers believe that the concept of ecotourism is equal to the above-mentioned concepts. But in the international context, the above concepts are totally different from ecotourism. As a result, ecotourism concept practiced in the eco resort is also different from the global standards. Eco tourists look at the concept of ecotourism in global standards, but the practice in Sri Lanka is different from it. Then, there is a mismatch of the practice and the expectations of eco tourists. Even though eco resort hoteliers have used the term "eco" in their resorts, they actually practice nature tourism, wildlife tourism, environment conservation tourism, and the combination of nature and cultural tourism. This is one of the reasons to dissatisfy the real eco tourists who visited Sri Lanka.

As we pointed out earlier, if a resort wants to use the term "eco" in a resort, they have to satisfy ecotourism components. They are natural area focus, interpretation, environmental sustainability practice, contribution to conservation, benefiting local communities, cultural respect, customer satisfaction, and responsible marketing. 
After analyzing all these components, we found that respondents have not considered some aspects that are internationally accepted in eco resorts, such as cultural respect, responsible marketing, and customer satisfaction. Even though they have mentioned the practices of other components under their in-depth interviews and discussions, they could not recognize them as the major components of an eco resort except the conservation of environment. Therefore, we found some deviations of them with international requirements.

For example, some hoteliers identified Corporate Social Responsibility (CSR) activities under the component of local community benefits. In the eco resort concept, providing well-being of the local community means activities which develop the living standards of the local community and involve them in the business process as a stakeholder. Then, they only feel as a part of the business and work for the development of the area. Therefore, CSR cannot be considered purely under the component of local community benefits. It is only a one-way process rather than a participative effort of both community and the business owners.

In another case, many hoteliers are launching awareness programs and interpretation programs to their stakeholders about the environmental conservation practices of the resorts and the hotel facilities. Therefore, they believe that they satisfy the interpretation component of the eco resort. But here, they consider the awareness programs of the conservation practices. It is not about the eco resort and ecotourism concepts. Therefore, they could not achieve the main purpose of their programs. The interview analysis also proved that almost all the levels of the eco resort staffs in the selected resorts are having a rather poor knowledge of the eco concepts. That is mainly due to the failure to launch correct awareness programs on the eco concept. That is the reason why they are having improper practices of the concept. In the case of responsible marketing, there were a lot of issues in those resorts such as providing wrong information to customers, wrong data in the web, sending inappropriate customers, coordination errors, etc.. It clearly showed that they were unable to pay their attention to the marketing aspects of the eco resorts and consider it as a main component.

As the hoteliers define the meaning of the ecotourism concept in a different manner, their practices also differ from the genuine concept. Therefore, we found that the hoteliers did not concern about the above components that much. They only address few components in their eco resorts. They do not consider them as a whole. As a result, the practice of eco concept in the resort has been challenged by the eco tourists who visited them. Even though the hoteliers satisfy the other customer segments' needs and requirements, they do not consider the eco tourists' needs as the major customer segment. The reason for this is the failure to identify the true customer segment properly.

In the ranking analysis of observation checklist points, the average values of checklist points under each component were calculated and compared. The results obtained from observations were analyzed using the ranking analysis method. It is a quantitative analysis method that calculates the mean value of each component to identify the priority given to them in the resorts' practices. Mean values for each eco resort were identified using the formula of mean.

Mean for each eco resort:

$$
\bar{X}=\frac{\sum_{i=1}^{7} X_{i}}{n}
$$

where:

$\sum=$ Summation of each component $(x)$ value;

$n=$ Number of components. 
The mean score (from $1=$ Not practicing ecotourism components at all to $5=$ Practicing ecotourism components a great deal) was used to rank the components of ecotourism practice in the research. Mean for each ecotourism component was calculated as follows:

$$
\bar{X}=\frac{\sum_{i=1}^{32} X_{i}}{n}
$$

$\sum=$ Summation of each component of all 32 resorts $(x)$;

$n=$ Number of resorts.

The average values of checklist points under each component were calculated and shown in Table 2.

Table 2

Collected Observations on Seven Ecotourism Components

\begin{tabular}{|c|c|c|c|c|c|c|c|c|}
\hline No. & $\begin{array}{l}\text { Natural area } \\
\text { focus }\end{array}$ & Interpretation & $\begin{array}{l}\text { Environmental } \\
\text { sustainability } \\
\text { practice }\end{array}$ & $\begin{array}{l}\text { Contribution to } \\
\text { conservation }\end{array}$ & $\begin{array}{l}\text { Benefits to } \\
\text { local } \\
\text { community }\end{array}$ & $\begin{array}{l}\text { Cultural } \\
\text { respect }\end{array}$ & $\begin{array}{l}\text { Responsible } \\
\text { marketing }\end{array}$ & Mean $\bar{X}$ \\
\hline 1 & 4.40 & 2.00 & 3.70 & 5.00 & 5.00 & 3.00 & 3.00 & 3.73 \\
\hline 2 & 4.40 & 2.25 & 3.80 & 4.60 & 4.00 & 2.00 & 2.00 & 3.29 \\
\hline 3 & 3.80 & 1.50 & 2.80 & 4.00 & 4.50 & 3.50 & 4.00 & 3.44 \\
\hline 4 & 4.00 & 2.50 & 2.50 & 4.80 & 5.00 & 2.00 & 2.50 & 3.33 \\
\hline 5 & 4.00 & 3.50 & 1.80 & 3.80 & 4.50 & 3.50 & 3.00 & 3.44 \\
\hline 6 & 2.80 & 1.50 & 2.90 & 2.80 & 3.50 & 2.00 & 2.00 & 2.50 \\
\hline 7 & 2.40 & 2.25 & 2.30 & 2.00 & 2.00 & 1.00 & 2.00 & 1.99 \\
\hline 8 & 3.80 & 2.75 & 4.00 & 3.20 & 2.50 & 1.50 & 1.50 & 2.75 \\
\hline 9 & 4.60 & 3.50 & 4.70 & 4.00 & 4.00 & 3.00 & 2.00 & 3.69 \\
\hline 10 & 4.40 & 4.00 & 4.20 & 4.80 & 4.00 & 2.00 & 1.50 & 3.56 \\
\hline 11 & 4.80 & 3.75 & 4.60 & 4.60 & 4.00 & 3.50 & 3.00 & 4.04 \\
\hline 12 & 2.80 & 1.75 & 2.10 & 2.80 & 3.00 & 2.50 & 2.00 & 2.42 \\
\hline 13 & 2.40 & 1.00 & 2.30 & 2.00 & 3.50 & 2.00 & 2.00 & 2.17 \\
\hline 14 & 4.20 & 3.25 & 4.30 & 4.60 & 4.00 & 2.50 & 2.00 & 3.55 \\
\hline 15 & 3.80 & 2.75 & 4.00 & 4.20 & 4.50 & 2.50 & 1.50 & 3.32 \\
\hline 16 & 4.40 & 3.75 & 4.40 & 4.80 & 4.50 & 2.00 & 1.50 & 3.62 \\
\hline 17 & 3.80 & 2.50 & 3.60 & 4.00 & 3.50 & 3.00 & 2.50 & 3.27 \\
\hline 18 & 3.00 & 2.00 & 2.40 & 2.80 & 2.50 & 1.50 & 2.00 & 2.31 \\
\hline 19 & 4.40 & 3.00 & 4.30 & 4.00 & 4.00 & 3.00 & 2.50 & 3.60 \\
\hline 20 & 4.00 & 2.75 & 3.90 & 4.40 & 4.50 & 2.00 & 1.50 & 3.29 \\
\hline 21 & 3.60 & 2.00 & 3.10 & 3.40 & 3.00 & 1.50 & 2.00 & 2.66 \\
\hline 22 & 4.60 & 3.00 & 4.60 & 4.60 & 4.50 & 2.50 & 2.00 & 3.69 \\
\hline 23 & 2.20 & 1.50 & 3.40 & 2.40 & 3.00 & 1.50 & 1.50 & 2.21 \\
\hline 24 & 3.80 & 2.50 & 3.90 & 4.00 & 4.00 & 4.00 & 2.50 & 3.53 \\
\hline 25 & 3.80 & 2.50 & 3.80 & 4.20 & 3.50 & 2.50 & 2.50 & 3.26 \\
\hline 26 & 2.40 & 1.50 & 2.70 & 2.00 & 2.00 & 1.50 & 1.50 & 1.94 \\
\hline 27 & 2.00 & 1.75 & 2.40 & 2.80 & 3.00 & 2.00 & 2.00 & 2.28 \\
\hline 28 & 4.20 & 2.50 & 4.40 & 4.60 & 4.50 & 1.50 & 2.00 & 3.39 \\
\hline 29 & 4.00 & 2.25 & 3.90 & 4.20 & 4.00 & 2.00 & 1.50 & 3.12 \\
\hline 30 & 4.20 & 3.75 & 3.90 & 4.80 & 4.50 & 2.50 & 3.00 & 3.81 \\
\hline 31 & 3.80 & 3.50 & 4.00 & 4.60 & 4.50 & 4.00 & 3.50 & 3.99 \\
\hline 32 & 4.80 & 3.75 & 4.60 & 4.60 & 5.00 & 3.50 & 3.00 & 4.18 \\
\hline
\end{tabular}


Here, the average value of 3 was taken as the boundary of the analysis (scale mean). If the components' mean values are higher than the average, it is considered as a good practice. If the mean values are lower than the average value, it is considered as a poor practice of the concept. In line with the overall mean values, 10 resorts were identified for poor practice of ecotourism concept.

Table 3

Ranking of Components

\begin{tabular}{ll}
\hline Component & Overall mean value \\
\hline Responsible marketing & 2.22 \\
Cultural respect & 2.41 \\
Interpretation & 2.59 \\
Environmental sustainability practice & 3.54 \\
Natural area focus & 3.74 \\
Benefits to local community & 3.83 \\
Contribution to conservation & 3.86 \\
\hline
\end{tabular}

Table 3 shows the ranking of the components of ecotourism practice. Contribution to conservation has the highest rank. This means that the contribution to conservation has become the most practicing component in most of the eco hotels. While responsible marketing has the lowest rank, which implies that most of the hoteliers are not properly practicing that component in their hotels. In addition to that, cultural respect and interpretation also have lower ranking showing less practice in Sri Lankan eco resort hotels. But environmental sustainability practices, benefits to local community, and natural area focus have higher values, implying higher usage among the selected components.

The mean values in Figure 2 show that 10 eco resorts from the total 32 are not following ecotourism practices at a satisfactory level. From those 10 resorts, five hoteliers are in totally poor side of practicing ecotourism practices. However, three eco resorts were identified to have practiced all the components successfully. Their values are higher than the scale mean (average mean). It is a very low percentage of the total number of resorts.

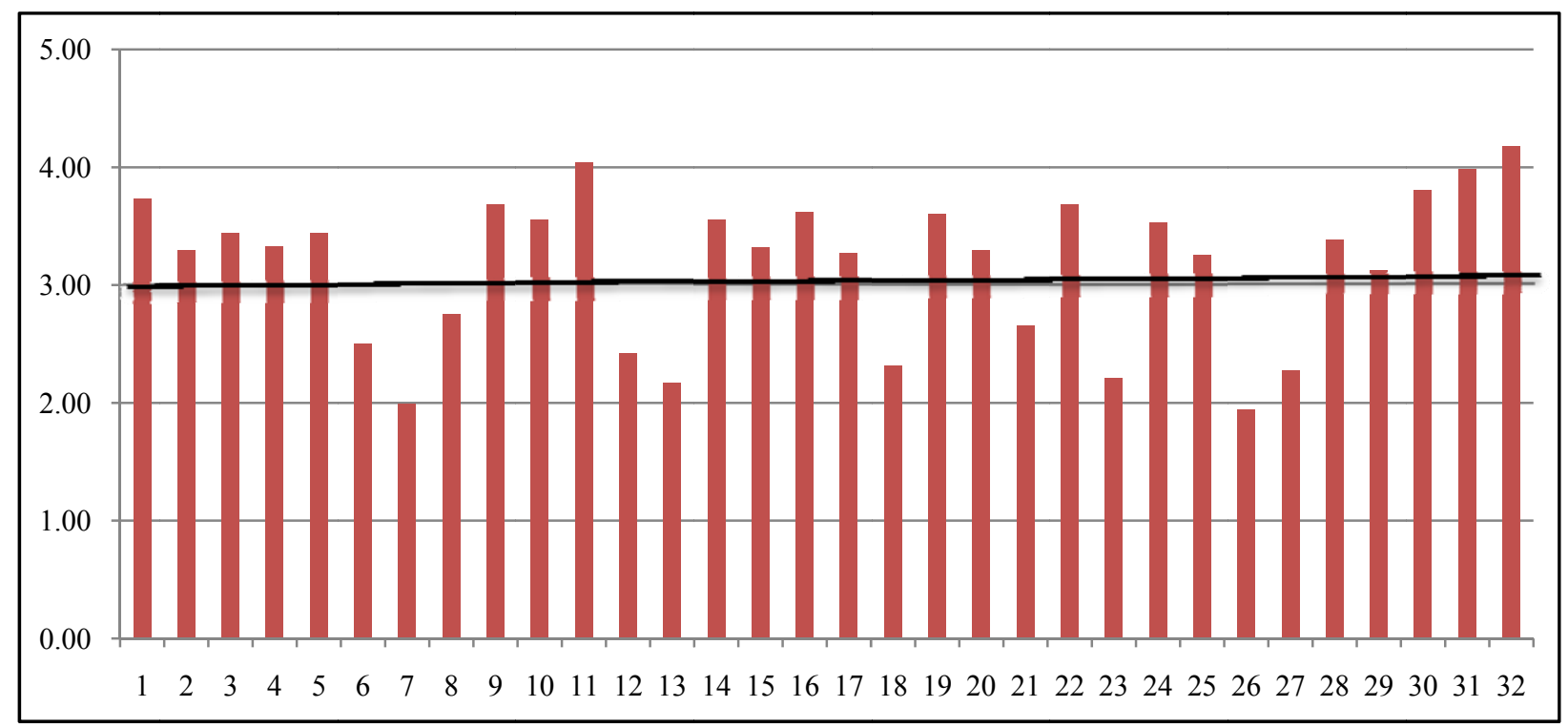

Figure 2. Mean values of 32 eco resorts. 
Observation analysis of the eco resorts showed that all the resorts were trying to address the conservation practices of environment, natural area focus, environmental sustainability practice, and benefiting local community. Even though the practices of these components were not correct, at least they have tried to launch some programs on those aspects. We identified these facts through the observations of the sub-components of each major component. In case of observations, we were able to recognize some similarities as well as disparities between the in-depth interview ideas of the hoteliers and the practice of the concept. It is specially relating to the practice of responsible marketing component. For example, in some resorts, resort is promoted as an eco-friendly resort in their web including some photos taken from the other resorts and activities which are not the practices in the resort. It is not responsible marketing. Even though the hoteliers said that they are satisfying the customers well, customers have complained about these practices.

Finally, the results of in-depth interview analysis showed a clear disparity between the eco tourists' views as the main customer segment and eco tourist hoteliers' views on the practice of eco resort concept. Hoteliers in the eco resorts have a fair knowledge of the practice of the main components of an eco resort, but they were unable to identify the importance of them to the main market segment. Even though Sri Lanka has a potential to practice the ecotourism and eco resort concept, the actual practices of hoteliers are deviating from the international standards. That is due to the variation of the construction of the meaning of ecotourism concept. It has led to negative impacts. As a result, hoteliers were unable to meet the customer expectations in order to achieve triple bottom line (economic sustainability, environmental sustainability, and socio-cultural sustainability) of the organization and tend to fail their eco resort business in the near future.

\section{Conclusion}

At the end of the research, we found that the practice of eco resort concept has been misused by the hoteliers in Sri Lanka as pointed out by the tourism professionals. But, they are not purposefully doing it. It is due to the lack of understanding of the concept. They are unable to classify the eco tourists and identify the market and customer segment clearly. They cater to different customer segments as eco tourists and earn profits neglecting the components of an eco resort. Further, we found that eco tourists' needs of eco resorts have not been addressed properly by the eco resort hoteliers. When the main guests are dissatisfied, there is a possibility of long-term dropping of the business. That is what they are starting to experience currently. It has created dissatisfaction to eco tourists who are moving away from the Sri Lankan ecotourism market to other destinations.

Attaching the "ecotourism" label to poorly planned programmes provides the local population with little besides social tension and environmental degradation, while leaving the genuine eco tourist dissatisfied and cheated. Most of the big resorts are just concrete jungles and still they claim themselves as eco resorts. Based on this research, the issue of failure to practice the eco resort concept happened due to the following reasons:

(1) Sri Lanka's ecotourism business is not being guided by international principles;

(2) A "National Policy Plan on Eco Tourism" is yet to be formulated by the tourism authorities in Sri Lanka;

(3) There are few true eco resort operators who adhere to the eco resort principles;

(4) There are few sufficient qualified people to handle eco tourists;

(5) Non-availability of genuinely planned eco resorts that guarantee the economic benefits to the community living around the eco resort areas. 
Therefore, there is a need to eliminate these adverse practices which threaten the healthy development of the ecotourism practices in Sri Lankan eco resorts.

\section{References}

Black, R. (1996). Ecotourism: What does it really mean? Ranger, 34, 4-7.

Boo, E. (1990). Eco tourism: The potentials and pitfalls (Vols. 1 \& 2). Washington, DC, USA: World Wildlife Fund.

Boyd, S. W., \& Butler, R. W. (1996). Managing ecotourism: An opportunity spectrum approach. Tourism Management, 17(8), 557-566.

Buckley, R. (1994). A framework for ecotourism. Annals of Tourism Research, 21(3), 661-665.

Burr, V. (2002). Social constructionism. London: Routledge.

Campbell, L. M. (1999). Ecotourism in rural developing communities. Annals of Tourism Research, 26(3), 534-553.

Ceballos-Lascurain, H. (2005). Ecotourism, practical ecotourism. Retrieved from http://www.planeta.com/ecotravel/weaving/hectorceballos.html

Che, D. (2006). Developing ecotourism in first world, resource-dependent areas. Geoforum, 37, 212-226.

Clarke, J. (1997). A framework of approaches to sustainable tourism. Journal of Sustainable Tourism, 5(3), 224-233.

Deaden, P., \& Harron, S. (1994). Alternative tourism and adaptive change. Annals of Tourism Research, 21(1), 81-102.

Font, X. (2002). Environmental certification in tourism and hospitality: Progress, process, and prospects. Tourism Management, 23(3), 197-205.

Geogakopoulou, A., \& Goutsos, D. (1997). Discourse analysis: An introduction. Edinburgh: Edinburgh University Press.

Gold, J., \& Holman, D. (2001). Let me tell you a story: An evaluation of the use of storytelling and argument analysis in management education. Career Development International, 6(7), 384-395.

Green Globe. (n.d.). Green Globe 21 standards. Retrieved from http://www.greenglobe21.com

Lindberg, K., Furze, B., Staff, M., \& Blank, R. (1997). Ecotourism and other services derived from forests in the Asia Pacific region: Outlook to 2010.

Lindergen, M., \& Packendorff, J. (2009). Social constructionism and entrepreneurship: Basic assumptions and consequences for theory and research. International Journal of Entrepreneurial Behavior and Research, 15(1), 25-47.

Mastny, L. (2002). Eco tourist trap. London: Spring.

Ross, S., \& Wall, G. (1999). Evaluating ecotourism: The case of North Sulawesi, Indonesia. Tourism Management, 20(6), 673-682.

Shanklin, C. W. (1993). Ecology age: Implications for the hospitality and tourism industry. Journal of Hospitality and Tourism Research, 17(1), 219-229.

Silva, D. C. (2004). Ecotourism: Sri Lanka's potential. President Ecotourism Society of Sri Lanka (ESSL). Retrieved from http://www.thinkgeography.org.uk/Thinkgeography/Ecotourism_files/Ecotourism\%20in\%20Sri\%20Lanka.pdf

Sri Lanka Tourism and Development Authority [SLTDA]. (2001). Mid-term strategic plan for Sri Lanka tourism 2002-2004 (pp. 1-35).

Sri Lanka Tourism and Development Authority [SLTDA]. (2003). Ecotourism development of Sri Lanka: National policy regulation and guidelines (pp. 1-31).

The International Ecotourism Society [TIES]. (1993). Eco tourism guidelines for nature tour operators. The International Eco Tourism Burlington, VT, USA.

The International Ecotourism Society [TIES]. (2000). Ecotourism statistical fact sheet.

The International Ecotourism Society [TIES]. (2006). TIES global ecotourism fact sheet.

Wunder, S. (2000). Ecotourism and economic incentives: An empirical approach. Ecological Economics, 32(3), 465-479. 